\title{
PROJETO GENOMA HUMANO E ÉTICA
}

\author{
Mayana Zatz \\ Professora de Genética Humana e Médica do Departamento de Biologia do Instituto de Biociências da Universidade de São Paulo, \\ Coordenadora do Centro de Estudos do Genoma Humano, Membro da Academia Brasileira de Ciências
}

\begin{abstract}
Resumo: Os avanços na tecnologia da biologia molecular têm sido tão rápidos que o número de testes genéticos disponíveis, tanto para características normais como patológicas, estão aumentando dia a dia. Enquanto questões éticas a ela relacionadas estão sendo debatidas no âmbito acadêmico, os laboratórios estão disputando a possibilidade de desenvolver e aplicar testes de DNA, pois do ponto de vista comercial os interesses são enormes. Neste artigo, ilustramos com alguns exemplos reais a complexidade de algumas situações e a dificuldade de se tomar decisões em benefício dos envolvidos, evidenciando a importância de se discutir questões éticas com toda a sociedade.

Palavras-chave: biologia molecular; ciência e ética; pesquisa e mercado.
\end{abstract}

$\mathrm{O}$ projeto genoma humano (PGH) tem como objetivo identificar todos os genes responsáveis por nossas características normais e patológicas. Os resultados a longo prazo certamente irão revolucionar a medicina, principalmente na área de prevenção. Será possível analisar milhares de genes ao mesmo tempo e as pessoas poderão saber se têm predisposição aumentada para certas doenças, como diabete, câncer, hipertensão ou doença de Alzheimer, e tratar-se antes do aparecimento dos sintomas. As vacinas de DNA poderão eliminar doenças como a tuberculose ou a Aids. Os remédios serão receitados de acordo com o perfil genético de cada um, evitando-se assim os efeitos colaterais. Paralelamente a esses avanços, inúmeras questões éticas já estão sendo discutidas e outras irão surgir. Mas, por enquanto, as implicações éticas, legais e sociais dos conhecimentos gerados pelo $\mathrm{PGH}$ em relação às características normais e patológicas e sua integração na clínica médica têm sido discutidas no ambiente acadêmico. Na prática, entretanto, já estão sendo desenvolvidos testes genéticos para a escolha do sexo de futuros bebês e bancos de DNA da população. Um número crescente de laboratórios oferece testes de DNA para doenças hereditárias ou para determinar se uma pessoa tem maior risco de desenvolver certas doenças como câncer ou doenças cardíacas. Será que as pessoas que se submetem a esses testes sabem o que exatamente está sendo testado? O que significa um teste positivo? O que significa um teste negativo?
Nos exemplos a seguir, veremos que a resposta a essas perguntas não é fácil e exige amplas discussões dos pontos de vista social, médico e principalmente ético.

\section{BANCOS POPULACIONAIS DE DNA: UM BENEFÍCIO OU UMA AMEAÇA?}

Em um artigo recente, Dawkins (1998) discute os prós e os contras de se ter um banco nacional com os dados de DNA ("fingerprint" ou impressões genéticas) da população. Seria um benefício ou uma ameaça? Na Inglaterra, onde já existe um banco de DNA com mais de 300 mil amostras, seus defensores argumentam que ele é muito importante para identificar criminosos ou infratores da lei. Mas quais seriam as possíveis implicações do uso negativo dessas informações, como por exemplo, em testes de paternidade? No livro $O$ animal moral: psicologia evolutiva e vida cotidiana, Robert Wright sustenta que a infidelidade tem razões genéticas mais fortes que os padrões morais. De acordo com essa hipótese, seria uma vantagem evolutiva para garantir descendentes "geneticamente melhores", isto é, a manutenção e propagação de genes "melhores". Realmente, estudos populacionais estimam que a taxa de falsa paternidade seja da ordem de $10 \%$ e, conseqüentemente, um grande número de homens acredita erroneamente que é o pai biológico de seus filhos, a maioria sem nenhum questionamento. Qual seria o impacto 
se, a partir de um banco de DNA da população, os "supostos pais" e seus filhos soubessem a verdade ou tais informações fossem utilizadas para chantagear as pessoas envolvidas?

Por outro lado, um número crescente de genes com suscetibilidade para algumas formas de câncer, doenças cardíacas ou doenças neurodegenerativas de início tardio (como mal de Alzheimer) está sendo identificado. As novas tecnologias que vêm sendo introduzidas permitirão, em pouco tempo, a identificação de centenas de genes "patológicos" em uma única reação. É inquestionável que as companhias de seguro-saúde e seguro de vida teriam o maior interesse em obter essas informações, isto é, saber que doenças teremos risco de desenvolver e a data prevista da nossa morte. E os nossos empregadores também não teriam interesse em obter tais informações sigilosas? A questão é: seremos capazes de manter o caráter confidencial de nosso perfil genético? Poderemos não concordar em nos submeter a um teste de DNA? Para aqueles que acreditam que implementar um banco de DNA da nossa população ainda é uma realidade distante, basta lembrar que recentemente se propôs que todos os recém-nascidos em São Paulo tivessem uma amostra de DNA coletada (a partir de sangue do cordão umbilical) para se obter uma impressão genética de cada um. Para encobrir os interesses comerciais (já que haveria um custo para cada exame), o motivo alegado foi evitar a troca de crianças em maternidade. E se essa coleta fosse obrigatória?

\section{GENES DE COMPORTAMENTO}

A influência genética em doenças psiquiátricas, tais como a doença do humor (ou psicose maníaco-depressiva), a esquizofrenia ou o alcoolismo, já é amplamente aceita (Alper e Natowicz, 1993; Mallet et alii, 1994). Em uma genealogia extensa da Holanda (Brunner et alii, 1993) identificaram, em indivíduos com comportamento agressivo e anti-social, uma mutação recessiva em um gene do cromossomo X (e que portanto só afeta indivíduos do sexo masculino). Essa mutação causa a deficiência de uma enzima, a momoamina oxidase A ou MAOA (responsável pelo metabolismo da dopamina, serotonina e noradrenalina). Felizmente, essa deficiência parece ser rara. Entretanto, outros estudos realizados em gêmeos (LaBuda et alii, 1993) sugerem que a delinqüência juvenil possa ter pouca influência genética, mas a delinqüência que persiste na idade adulta teria um componente genético importante.

Nos últimos anos, inúmeros pesquisadores vêm tentando identificar genes de suscetibilidade para doen- ças psiquiátricas ou distúrbios de comportamento. Descobriu-se, por exemplo, um polimorfismo ligado ao gene transportador da serotonina que causa uma recaptação diminuída dessa substância na fenda sináptica (Heil et alii, 1996). Trabalhos recentes confirmados na nossa população mostraram que pacientes com doença de Alzheimer (Oliveira et alii, 1998) e distúrbios psiquiátricos (depressão maior, distimia e doença bipolar) diferem quanto a esse polimorfismo em comparação com controles normais. Em um estudo muito interessante realizado na Noruega verificou-se que, entre os alcoólatras, aqueles que se tornam agressivos sob o efeito do álcool também diferem dos não-agressivos em relação a esse polimorfismo.

Trabalhos recentes em modelos animais têm mostrado que poderiam existir genes que levam ao alcoolismo ou à dependência de drogas, pois enquanto alguns se tornam dependentes outros têm aversão às mesmas substâncias (Crabbe et alii, 1994; Palmour et alii, 1997). O mesmo comportamento já havia sido observado em humanos, uma vez que um estudo realizado em um grupo de voluntários verificou que a injeção de heroína, em teste cego, provocava uma reação de prazer em alguns e de aversão em outros.

Outros trabalhos muito polêmicos sugerem que o homossexualismo masculino (Hu et alii, 1995), o "bomhumor" e o otimismo também teriam influências genéticas. Segundo os autores, os genes do "bom humor", por exemplo, atuariam no metabolismo das dopaminas ou serotoninas (Hamer, 1996). Enquanto os marcadores genéticos responsáveis pelo comportamento humano continuam sendo pesquisados, a questão central é o seu o uso para identificar traços de personalidade desejáveis ou não. E novamente as perguntas: Os indivíduos com predisposição genética para o alcoolismo ou para a dependência de drogas podem ser julgados culpados? O que são características indesejáveis? Agressividade? Preguiça? Homossexualismo? Mau humor? Os indivíduos portadores de genes "de distúrbios de comportamento" serão mais tolerados ou discriminados? Por outro lado, se soubermos que o mau humor tem uma explicação biológica teremos maior compreensão com as pessoas birrentas e constantemente mal-humoradas?

\section{ESCOLHA DE SEXO}

Uma outra questão ética é a possibilidade de se escolher o sexo de um futuro bebê. Na Inglaterra, Statham et 
alii (1993) enviaram a um grupo de cerca de 2.300 grávidas um questionário com as seguintes perguntas: você prefere um menino, uma menina ou é indiferente? A análise dos resultados mostrou que se a população da GrãBretanha pudesse escolher o sexo de seus futuros filhos isto não causaria um desbalanceamento sexual. Já na China, onde a maioria dos casais só tem um descendente, o aborto seletivo de fetos do sexo feminino já criou uma desproporção sexual gigantesca em favor do sexo masculino. E no Brasil, o que aconteceria se os casais pudessem optar pelo sexo de seus filhos?

Por outro lado, a possibilidade de se determinar o sexo de embriões antes da sua implantação (diagnóstico préimplantação na fertilização "in vitro") para casais com risco de doenças genéticas que só afetam o sexo masculino (como a hemofilia ou a distrofia de Duchenne) evitaria o diagnóstico pré-natal e o sofrimento de ter de interromper uma gestação no caso de fetos portadores. A seleção sexual de embriões por essa técnica, no entanto, é ética no caso de casais sem risco genético aumentado, que quiserem recorrer a essa prática somente para escolher o sexo de um futuro bebê? Em algumas sociedades, a herança material só passa de pai para filho se ele tiver descendentes do sexo masculino, isto é, não ter um filho varão pode significar perder toda a herança da família e ficar reduzido à pobreza. Não é difícil imaginar que a procura de testes pré-implantação para determinar o sexo deva ser muito grande nesses casos. Seria ético negar essa possibilidade em uma situação como essa?

\section{DOENÇAS GENÉTICAS}

Já no caso de doenças genéticas, a identificação de genes deletérios é fundamental para o diagnóstico diferencial de doenças clinicamente semelhantes, para a prevenção (pela identificação de portadores com risco de virem a ter filhos afetados e por diagnóstico pré-natal) e para futuros tratamentos.

Do ponto de vista ético, entretanto, a detecção de portadores de genes deletérios pode ter conseqüências totalmente diferentes, pois distinguem-se basicamente dois grupos: os portadores assintomáticos, nos quais o risco de uma doença genética só existe para a prole, como no caso da herança autossômica recessiva ou recessiva ligada ao X; e os portadores sintomáticos ou présintomáticos, nos quais o risco existe tanto para a prole e para si mesmos, como o caso da herança autossômica dominante.

\section{Detecção de Portadores Assintomáticos de Genes Deletérios}

Em relação a testes genéticos neste grupo, os exemplos seguintes levantam outras questões, tais como: Até onde vai o nosso direito de interferir? Devemos sempre dizer a verdade? Podemos nos negar a fazer um teste genético?

Uma consulente vem procurar um serviço de Aconselhamento Genético para diagnóstico pré-natal. O levantamento da genealogia mostrou que seu pai é hemofílico, o que significa que ela é portadora assintomática deste gene e portanto um feto, de sexo masculino, terá uma probabilidade de $50 \%$ de vir a ser afetado por hemofilia. Inesperadamente, o estudo de DNA da consulente e de seus pais revela que "o suposto pai hemofílico" não é na realidade o seu pai biológico. Isso significa que a consulente não é portadora do gene da hemofilia e portanto não existe risco para esta ou futuras gestações, o que dispensa a realização de qualquer teste genético. É ético revelar à consulente que "seu pai não é seu pai" e arriscar a desestruturação de uma família aparentemente unida? Ou, por outro lado, é ético submeter a paciente a um exame pré-natal desnecessário, sabendo-se de antemão que não somente esta como futuras crianças dessa consulente não têm risco de hemofilia?

Em outro caso, a consulente tem um filho afetado por distrofia de Duchenne (DMD), uma doença letal grave, cujos afetados raramente ultrapassam a terceira década. O exame de DNA revela que tanto a consulente como sua mãe são portadoras do gene da DMD e, portanto, há um risco de $50 \%$ de virem a ter descendentes de sexo masculino com DMD. Durante o Aconselhamento Genético (AG) a consulente é informada sobre seu risco genético e que suas tias, primas e sobrinhas, também em risco de serem portadoras do gene da DMD, podem recorrer ao exame de DNA para tentar prevenir o nascimento de novos afetados. A consulente, entretanto, nega-se terminantemente a alertar seus familiares sobre esse risco.

Pergunta-se: É ético deixar que pessoas em risco ignorem essas informações que poderiam prevenir o nascimento de uma criança afetada por uma doença genética grave? Por outro lado, temos o direito de invadir a privacidade dos outros? Ou quebrar o princípio da confidencialidade deve ser uma norma no AG?

Um terceiro exemplo ilustra uma situação ainda mais complicada. Uma consulente adolescente é encaminhada para diagnóstico pré-natal pois tem dois irmãos afetados por DMD. O estudo de DNA revela que ela é portadora do gene da DMD e, portanto, existe $50 \%$ de risco de que 
venha a ter um filho afetado. Antes de realizarmos o estudo de DNA do feto, entretanto, somos informados de que há uma suspeita de que o pai biológico da criança seria o próprio pai da consulente. Somos consultados sobre a possibilidade de confirmar essa suspeita, pelo exame de DNA, sem o conhecimento da consulente. Do ponto de vista genético, o risco de uma criança, fruto de uma relação incestuosa (pai-filha), ser afetada por uma doença genética (retardo mental, doenças recessivas ou malformação congênita) é da ordem de $50 \%$, independentemente do sexo. Ou seja, é um risco tão grande quanto o da DMD, mas neste caso sem possibilidades de um diagnóstico pré-natal. As grandes questões são: a) é ético realizar um exame de DNA sem o prévio consentimento dos interessados?; b) ou é mais ético não realizar esse exame, mesmo sabendo do alto risco para o feto e da possibilidade, neste caso, de se interromper a gestação com amparo legal?

\section{Testes Moleculares em Doenças Dominantes de Início Tardio. Doenças Ainda sem Tratamento: o Exemplo dos Genes Dinâmicos}

Em doenças como a Coreia de Huntington $(\mathrm{CH})$ ou $a$ Distrofia Miotônica de Steinert (DMS), os portadores, além de manifestar a patologia, têm um risco de $50 \%$ de vir a transmitir o gene defeituoso para a sua descendência. $\mathrm{Na} \mathrm{CH}$ [causada por uma expansão do número de repetições $(\mathrm{CAG})_{\mathrm{n}}$ no gene huntingtina (Kremer et alii, 1994)] o quadro clínico geralmente tem início após a quarta ou quinta década, e leva a uma demência progressiva e irreversível.

Na DMS [causada por uma expansão de repetições $(\mathrm{CTG})_{\mathrm{n}}$ no gene da proteína-quinase da distrofia miotônica (Brook et alii, 1992)] a situação é um pouco diferente, pois o quadro clínico é muito variável. Indivíduos portadores do gene podem ter como único sinal clínico uma calvície precoce ou catarata em idade avançada, enquanto no outro extremo existem aqueles que apresentam um quadro grave, com início na infância, manifestado por: retardo mental, desenvolvimento, fraqueza e degeneração muscular e esterilidade no sexo masculino. A forma clássica, a mais comum, tem início em geral na idade adulta.

As questões éticas que se colocam são: quais seriam os prós e os contras de se testar crianças assintomáticas, descendentes de afetados, e saber de antemão se elas são portadoras do gene da $\mathrm{CH}$ e DMS? Os defensores do teste présintomático argumentam que saber precocemente seria importante na escolha da futura profissão. Por exemplo, poderiam ser evitadas aquelas que requerem habilidade manual, pois é a primeira a ser comprometida no caso da DMS. Por outro lado, vale a pena angustiar-se antecipadamente e saber que se tem uma doença para a qual não existe cura? A pesquisadora Nancy Wexler, cuja mãe morreu de $\mathrm{CH}$ pergunta: você quer saber quando e como vai morrer?

Após inúmeras discussões éticas internacionais a respeito, o consenso foi não realizar testes pré-sintomáticos em crianças, com risco para doenças genéticas de manifestação tardia, para as quais ainda não há tratamento. $\mathrm{O}$ argumento mais forte é que ao testar crianças assintomáticas estaremos negando-lhes o direito de decidir, quando adultas, se querem ou não ser testadas. A nossa experiência pessoal mostra que essa conduta talvez seja a mais adequada, pois recentemente vários jovens adultos "em risco" foram informados de que já existia um teste de DNA para confirmar se eram ou não portadores do gene. Nenhum deles, no entanto, quis se submeter ao teste, o que mostrou que "viver na incerteza" talvez seja mais tolerável do que o risco de "ter certeza".

\section{Genes de Risco para Doenças com Possível Tratamento: o Exemplo dos Genes BRCA1 e BRCA2 de Suscetibilidade para Câncer de Mama Hereditário}

Mulheres portadoras de mutações nos genes BRCA1 e BRCA2 têm um risco de cerca de $80 \%$ de desenvolver câncer de mama e um risco aumentado para câncer de ovário (Ponder, 1997). A identificação desses genes levou vários laboratórios a oferecer testes de DNA (a custos altíssimos) à população feminina, supostamente para identificar as pessoas portadoras de mutações nesses genes e poder oferecer um tratamento preventivo àquelas com resultados positivos. Para as mulheres com história familiar de câncer de mama a detecção precoce pode ser muito importante para o tratamento preventivo. Entretanto, a questão ética é se esses testes devem ser feitos na população feminina em geral. Isso porque o risco global (life time risk) que uma mulher, sem história familiar, tem de desenvolver um câncer de mama ao longo da vida é da ordem de $10 \%$, enquanto o câncer hereditário constitui apenas $1-2 \%$ dos casos. Assim, é dez vezes mais provável que, se uma mulher vier a desenvolver um câncer de mama, ele não esteja relacionado a mutações nos genes BRCA1 e BRCA2. A questão ética é: será que uma mulher cujo teste não revelou mutações nos genes BRCA1 e BRCA2 sabe disso ou vai ficar tranqüila achando que está livre do 
risco de ter câncer de mama? Além disso, como existem centenas de mutações patológicas ao longo desses genes (e é ainda inviável testar todas elas), os laboratórios testam apenas as mais comuns, o que levanta outra questão: sabemos exatamente o que está sendo testado?

\section{DIAGNÓSTICO PRÉ-NATAL E O PROBLEMA ÉTICO DA INTERRUPÇÃO DA GESTAÇÃO}

Os problemas éticos relacionados com o diagnóstico pré-natal e interrupção de gravidez de fetos portadores de genes deletérios também têm sido amplamente discutidos. No caso de doenças letais (na primeira ou segunda décadas) ou as incompatíveis com uma vida independente (como aquelas que causam um retardo mental profundo), a decisão para um casal em risco de interromper uma gestação é mais fácil. Por outro lado, para aquelas de início tardio ou prognóstico indefinido, como a $\mathrm{CH}$ ou a DMS, o questionamento é enorme. Alguns indivíduos alegam que não querem transmitir esse gene para a sua descendência, mas será que não existirá uma cura definitiva nas próximas décadas? $\mathrm{Ou}$, podemos garantir que um filho nosso terá uma vida saudável por muitas décadas?

É fundamental salientar que vários centros do mundo que realizam diagnóstico pré-natal mostraram que a legislação a favor da interrupção da gestação no caso de fetos certamente portadores de genes deletérios tem reduzido significativamente o número de abortos em famílias com risco genético. Isso porque muitos casais decididos a interromper uma gravidez no caso de um feto "em risco" deixaram de abortar quando o diagnóstico pré-natal de certeza comprovou um feto normal para aquela doença. De fato, no nosso laboratório, onde já foram realizados mais de 100 exames de diagnóstico pré-natal em casais em risco (para diferentes formas de distrofias musculares, atrofia espinhal e fibrose cística), somente cerca de $10 \%$ foram diagnosticados como afetados. Portanto, o diagnóstico pré-natal de certeza e a possibilidade do aborto terapêutico têm salvado inúmeras vidas normais. Por isso a importância fundamental de discussões éticas em torno da legalização da interrupção da gestação no caso de doenças graves ou incuráveis, pois as nossas leis certamente não têm acompanhado os avanços das pesquisas.

\section{CONCLUSÃO}

Em resumo, os avanços na tecnologia da biologia molecular têm sido tão rápidos que o número de testes genéticos disponíveis, tanto para características normais como patológicas, estão aumentando dia a dia. Enquanto as questões éticas estão sendo debatidas no âmbito acadêmico, os laboratórios estão disputando a possibilidade de desenvolver e aplicar testes de DNA, pois do ponto de vista comercial os interesses são enormes. Só para exemplificar, estima-se que nos Estados Unidos (Nowak, 1994) haveria cerca de 30 mil famílias em risco para a doença de Huntington, 36 mil famílias para distrofia miotônica, de três a cinco milhões de pessoas para doença de Alzheimer e um milhão de mulheres portadoras de mutações nos genes BRCA1 e BRCA2. As questões que precisam ser debatidas do ponto de vista médico, social e ético são:

- Qual é o benefício de testes pré-sintomáticos?

- As pessoas sabem para quê estão sendo testadas, o que significa um teste positivo ou um resultado negativo?

- Quem irá regular a produção e o uso de testes genéticos, a sua qualidade e o acesso da população a eles?

- Quando oferecer testes?

- Empregadores e companhias de seguro-saúde terão acesso às informações?

- Quem vai controlar a confidencialidade?

- Poderemos nos negar a ser submetidos a um teste genético?

- Quem vai interpretar os resultados e ser responsável pelo aconselhamento genético?

- Quem vai controlar os aspectos éticos?

- Estamos preparados para lidar com essa avalanche de novos conhecimentos que serão gerados pelo Projeto Genoma Humano?

\section{NOTAS}

E-mail da autora:mayazatz@usp.br

Gostaria de agradecer a uma "superequipe de colaboradores" do Centro de Estudos do Genoma Humano e da ABDIM (Associação Brasileira de Distrofia Muscular) que muito tem contribuído para as discussões éticas aqui relatadas e à Fapesp, $\mathrm{CNPq}$ e Pronex pelo apoio constante que têm dado à nossa pesquisa.

\section{REFERÊNCIAS BIBLIOGRÁFICAS}

ALPER, J.S. e NATOWICZ, M.R. "On establishing the genetic basis of mental disease". Trends in Neuroscience, v.16, 1993, p.387.

BROOK, J.D.; MCCURRACH, M.E.; HARLEY, H.G. et alii. "Molecular basis of myotonic dystrophy: expansion of a a trinucleotide (CTG) repeat at the 3 'end of a transcript encoding a protein kinase family member". Cell n.68, 1992, p.799-808. 
BRUNNER, H.G.; NELEN, M.; BREAKEFIELD, O.; ROPERS, H. e VAN OOST, B.A. "Abnormal behavior associated with a point mutation in the structural gene for monoamine oxidase A". Science, n.258, 1993, p.668.

CRABBE, J.C.; BELKNAP, J.K. e BUCK, K. "Genetic animal models of alcohol and drug abuse". Science, n.264, 1994, p.1715-1723.

COLLINS, F.S.; PATRINOS, A.; JORDAN, E.; CHAKRAVARTI, A. GESTELAND R.; WALTERS, LEROY et alii. New goals for the U.S. human genome project. 1998 , p. 1.998-2.003.

DAWKINS, R. “Arresting evidence”. Sciences, 1998, p.20-25.

HAMER, D.H. "The heritability of happiness". Nature Genetics, n.14, 1996, p.125126.

HARLEY, G.H.; BROOK, J.D.; RUNDLE, S.A; CROW, S.; REARDON, W.; BUCKLER, A.J.; HARPER, P.S. et alii ."Expansion of an unstable DNA region and phenotypic variation in myotonic dystrophy". Nature, n. 355, 1992, p.545-546.

HEIL, A.; TEUFEL, A.; PETRI, S.; STOBER, G.; RIEDERER, P.; BENGEL, D. e LESCH, K.P. "Allelic variation of human serotonin transporter gene expression". Journal of Neurochemics, n.66, 1996, p.2621-2626.

HU, S.; PATTATUCCI, A.M.; PATTERSON, C.; LIN, L.; FULKER, D.W.; CHERNY, S.C.; KRUGLYACK, L. e HAMER, D.S. "Linkage between sexual orientation and chromosome Xq28 in males but not in females". Nature Genetics, n.11, 1995, p.248-256.

KREMER, B.; GOLDBERG, P.; ANDREW, S.E.; THEILMANN, J.; TELENIUS, H.; ZEISLER, J.; SQUITIERI, F. et alii. "A worldwide study of the Huntington's disease mutation: the sensitivity and specifity of measuring CAG repeats". N. Engl. J. Med., n.330, 1994, p.1401-1406.

LaBUDA, M.C.; GOTTESMAN II e PAULS, D.L. "The usefulness of twin studies for exploring the etiology of childhood and adolescent psychiatric disorders". Am. J. Med. Genet., n.48, 1993, p.47-59.
LESCH, K.P.; BENGEL, D.; HEILS, A.; SABOL, S.Z.; GREENBERG, B.D.; PETRI, S.; BENJAMIN, J.; MULLER, C.R.; HAMER, D.H. e MURPHY, D.L. "Association of anxiety-related traits with a polymorphism in the serotonin transporter gene regulatory region". Science, n. 274, 1996, p.15271531.

MALLET, J.; MELONI, R. e LAURENT, C. "Catecholamine metabolism and psychiatric or behavioral disorders". Curr. Opinion. Genet. Develop., n.4, 1994, p.419-426.

MANN, C. "Behavioral genetics in transition". Science, n.264, 1994, p.1.6861.695 .

MCKUSICK, V. e AMBERGER, J.S. "The morbid anatomy of the human genome: chromosomal location of mutations causing diseases". J. Med. Genet, 1994, p.265-279.

NOVAK, R. "Genetic testing set for takeoff”. Science, n.265, 1994, p.464- 467.

OLIVEIRA, J.R.M.; GALLINDO, R.M.; MAIA, L.G.S.; BRITO-MARQUES, P.R.; OTTO, P.A.; PASSOS-BUENO, M.R.; MORAIS JR., M.A. e ZATZ, M. "The short variant of the polymorphism within the promoter region of the serotonin transporter gene is a risk factor for late onset Alzheimer's disease". Molecular Psychiatry, n.3, 1998, p.438-441.

PALMOUR, R.M.; MULLIGAN, J.; HOWBERT, J.J. e ERVIN, F. "Insigths from model systems: of monkeys and men: vervets and the genetics of human-like behaviors". Am. J. Hum. Genet., n.61, 1997, p.481-488.

PLOMIN, R.; OWEN, M.J. e MCGUFFIN, P. "The genetic basis of complex human behavior". Science, n.264, 1994, p.1.733-1.737.

PONDER, B. "Genetic testing for cancer risk". Science, n.278, 1997, p.1.0501.054 .

STATHAM, H.; GREEN, J.; SNOWDON, C. e FRANCE-DAWSON, M. "Choice of baby's Sex". Lancet, n.341, 1993, p.564-565. 